Article

\title{
Evidence of Segmentation in the Iberia-Africa Plate Boundary: A Jurassic Heritage?
}

\author{
Manel Fernàndez *, Montserrat Torne ${ }^{\circledR}$, Jaume Vergés, Emilio Casciello and Chiara Macchiavelli \\ Group of Dynamics of the Lithosphere, Institute of Earth Sciences Jaume Almera (ICTJA-CSIC), \\ Consejo Superior de Investigaciones Científicas, 117, 28006 Madrid, Spain \\ * Correspondence: mfernandez@ictja.csic.es
}

Received: 5 July 2019; Accepted: 30 July 2019; Published: 7 August 2019

check for updates

\begin{abstract}
The present structure of the Iberia-Africa plate boundary between the Gorringe Bank and the Algerian Basin is characterized by a highly segmented geometry and diffused seismicity. Filtered Bouguer gravity data show conspicuous highs coinciding with the Gorringe Bank, the Guadalquivir-Portimao Bank, and the Ronda/Beni-Bousera massifs, reflecting the current geometry of the plate boundary segments. The Africa-Eurasia Alpine convergence produced crustal-scale thrusting in the Atlantic segments and roll-back subduction in the Ligurian-Tethys segments. Despite the growing consensus that the Gorringe and the Guadalquivir-Portimao Banks resulted from tectonic inversion of hyperextended margin structures inherited from the Early Jurassic, this heritage is more debatable for the Ronda/Beni-Bousera massifs lacking models linking the Atlantic and Mediterranean realms. On the basis of gravity analysis combined with plate reconstruction models, geological cross-sections, and recent local tomography, we infer a strong Jurassic heritage of the present-day segmentation and substantiate a comprehensive tectonic evolution model of the Iberia-Africa plate boundary since the Early Jurassic to Recent that includes the Atlantic and the Mediterranean domains.
\end{abstract}

Keywords: gravity modelling; hyper-extended margin segments; tectonic reconstruction; Atlantic-Mediterranean domains

\section{Introduction}

Jurassic Tethys segmentation in the Eurasia-Africa plate boundary has been proposed from plate reconstruction models [1,2], but the location, extent, and evolution of these segments is uncertain owing to their obliteration during the Alpine orogeny. The diffuse character of the plate boundary, with deformation spreading over a wide region encompassing the whole Betic-Rif orogenic system [3], obscures the possible tectonic reconstructions favoring the emergence of many competing geodynamic models [4-7].

Unravelling the evolution of the Iberia-Africa plate boundary, hereinafter the IAPB, is troublesome because (i) from the Early Jurassic to the Early Oligocene, the Iberian plate moved independently of the large and limiting African and Eurasian plates [1,2]; and (ii) there is a marked heterogeneity in the nature and age of the lithosphere along this boundary, changing from an old Jurassic oceanic domain in the Atlantic to a young Miocene back-arc domain, with a highly extended continental crust that transitions eastwards to an oceanized crust, in the Mediterranean [8]. The opening of the Central Atlantic during the Early Jurassic caused the eastward migration of Africa relative to Iberia, generating the Ligurian-Tethys domain, which was formed by several transtensive and highly extended continental segments transitioning to oceanic lithosphere further east [2]. Transtension in the Ligurian-Tethys ceased during the Early Cretaceous, when the Mid-Atlantic ridge propagated northwards along the Newfoundland-Iberia margin, triggering the eastward motion of the Iberian plate 
and the opening of the Bay of Biscay [9]. The protracted N-NNW displacement of Africa relative to Eurasia since the Late Cretaceous has been accommodated by the consumption of the Ligurian-Tethys domain, by the formation of the Pyrenees in the northern Iberia margin, and by significant intraplate deformation $[10,11]$.

The Azores-Gibraltar Fracture Zone (AGFZ), west to the Gorringe Bank, constitutes the Atlantic segment of the IAPB and is characterized by a tectonic regime varying from transtensive in the west to transpressive in the east, with a strike-slip motion in its central part [12]. The main elements resulting from this tectonic regime east of the Gloria Fault are as follows (Figure 1): (i) the Gorringe Bank, a $5 \mathrm{~km}$ high seamount separating the Tagus and the Horseshoe abyssal plains; (ii) the Gulf of Cadiz Imbricated Wedge, the accretionary prism of the subduction-related Betic-Rif orogen; and (iii) the Alboran basin, a back-arc basin formed by the roll-back of the Ligurian-Tethys subducting slab and the migration of the Betic-Rif front.

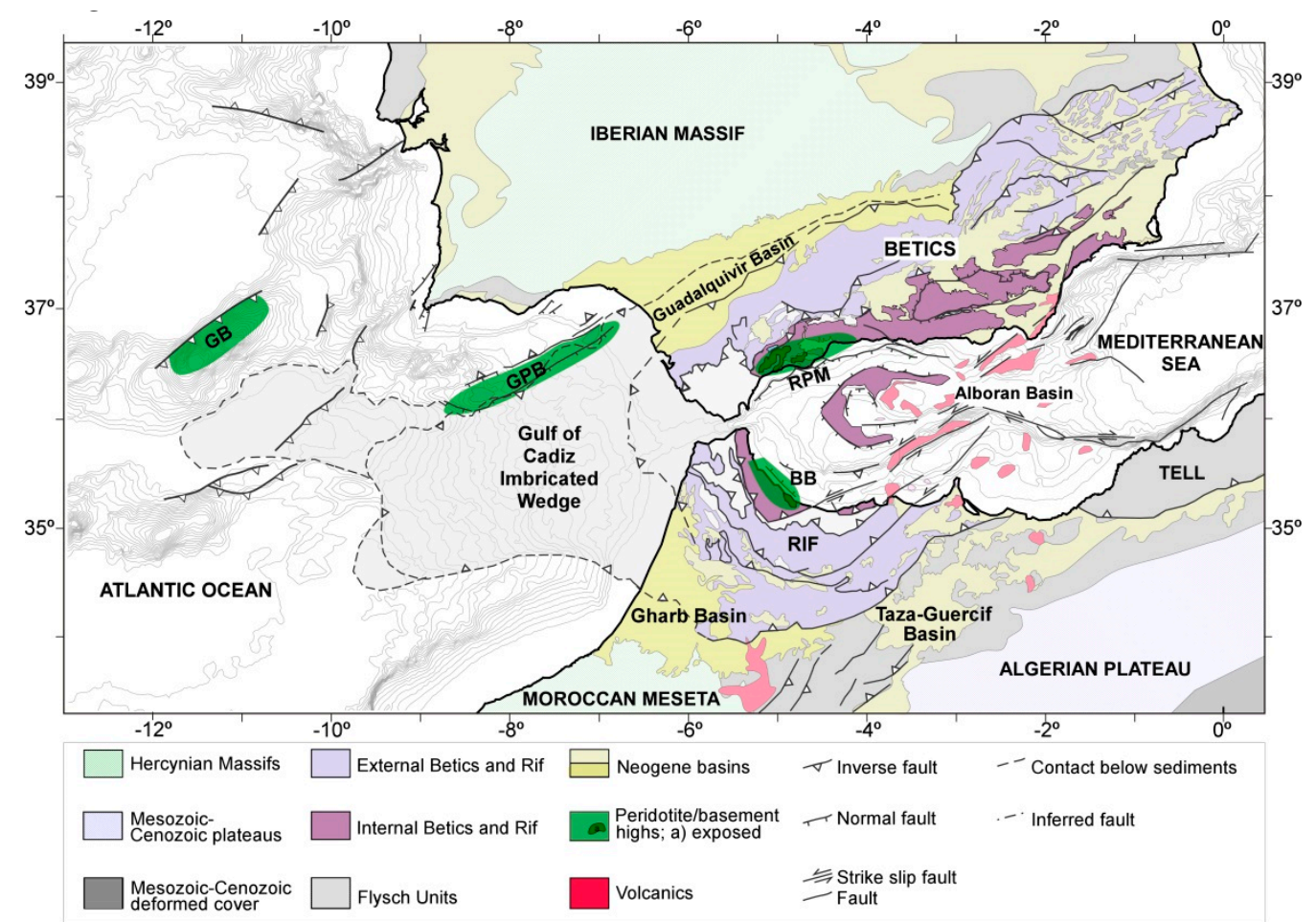

Figure 1. Simplified geologic and tectonic map of the Iberia-Africa plate boundary region modified from the works of $[13,14]$. Shaded green areas denote main compressive structures with outcropping or in-depth exhumed mantle rocks. GB: Gorringe Bank; GPB: Guadalquivir-Portimao Bank; RPM: Ronda Peridotite Massif; BB: Beni-Bousera peridotites.

Geophysical evidence reveals that the plate boundary is relatively narrow to the west of the Gorringe Bank along the Gloria Fault, whereas deformation spreads over a much broader region to the east towards the Betic-Rif orogenic system and the inner back-arc Alboran basin $[3,12,14,15]$. The present-day geometry of the AGFZ shows large-scale fault displacements in its eastern segment, with a total NNW Iberia-Africa convergence of 120-130 km increasing to 200-230 km in the Alboran region, $35 \%$ of which occurred prior to late Eocene $[16,17]$.

The proposed geodynamic models for the IAPB region depend largely on whether they focus on the Atlantic or the Mediterranean domains, and a comprehensive model that includes the whole region is still lacking $[5-7,18,19]$. The main discrepancies refer to the Mediterranean region, particularly regarding whether the subduction of the Tethys was initially directed to the NW, SE, or E; whether it was continuous or highly fragmented; and whether it was connected to the Atlantic, or restricted to the central Ligurian-Tethys domain with large westward displacements of the subduction front $[6,7,18,19]$. 
Here, we present a gravity based modeling that, combined with previous interpretations of seismic data and tectonic models, has allowed us to interpret the present location, length, and structure of the Iberian margin segments, and propose a tectonic model of the IAPB from Early Jurassic to Present, including, as a novelty, the Atlantic and the Mediterranean domains.

\section{Gravity Response to Tectonic Inversion of Iberia-Africa Hyper-Extended Margin Segments}

After the eastward displacement of Africa relative to Iberia during the Jurassic and the Lower Cretaceous, the far-field stresses changed and Africa moved northwards against Iberia, producing compression and inversion of previous basins. According to the authors of $[11,16]$, the Africa-Europe convergence was accommodated along the two Iberian plate boundaries (Betic-Rif and Pyrenees) since the latest Santonian. The end of shortening across the Pyrenees occurred during the latest Oligocene, whereas it continued until present across the Betic-Rif system, but at lower convergence rates. The tectonic inversion of the hyper-extended segments of the Ligurian-Tethys domain since the Campanian $(83.5 \mathrm{Ma}$ ) resulted in transpressive structures characterized by crustal-scale thrusting and basement highs west of the Gibraltar Strait in the Atlantic domain, and by the stacking of internal high-pressure / low-temperature (HP/LT) tectonic units of the Betics and Rif exhumed along the interface of the retreating subducting plate in the Mediterranean domain (Figure 1). All these structures may be reflected through the gravity field, allowing mapping of their location and extent. The Bouguer gravity anomaly map (Figure 2) was extracted from the global marine gravity model offshore using a density reduction of $2670 \mathrm{~kg} / \mathrm{m}^{3}$ [20], and from a recent compilation onshore [21]. The map shows that positive anomalies are located in the oceanic domain and in much of the onshore of the southwestern Iberian Peninsula, whereas negative values are related to the Betic-Rif orogen, the eastern and southern sectors of the Gulf of Cadiz, and the westernmost Alboran basin coinciding with crustal thickening and thick sedimentary depocenters.

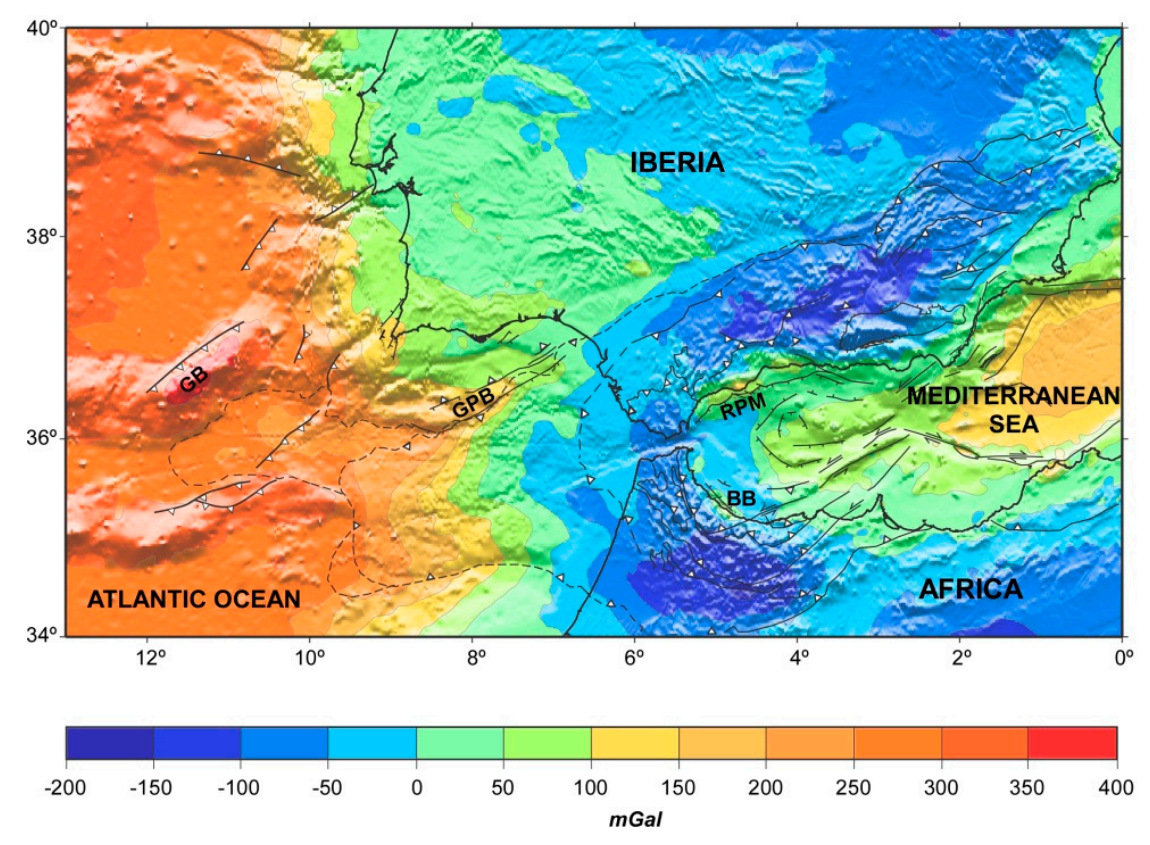

Figure 2. Bouguer gravity anomaly map of the Iberia-Africa plate boundary region. Tectonic background as in Figure 1. GB: Gorringe Bank; GPB: Guadalquivir-Portimao Bank; RPM: Ronda Peridotite Massif; BB: Beni-Bousera peridotites. 
After applying a high-pass-filter to the Bouguer anomaly map to enhance its short wavelength component (<200 km, Figure 3), we can distinguish prominent positive anomalies clearly associated with three main WSW-ENE structures oriented: the Gorringe Bank (GB), the Guadalquivir-Portimao Bank (GPB), and the Ronda Peridotite Massif (RPM), with the RPM extending some tens of km further east and south from the exposed massif. The three filtered gravity anomalies show similar amplitudes, in the range of 120-130 mGal, and wavelengths of $\sim 120 \mathrm{~km}$ (see inset in Figure 3), but are associated with different tectonic structures.

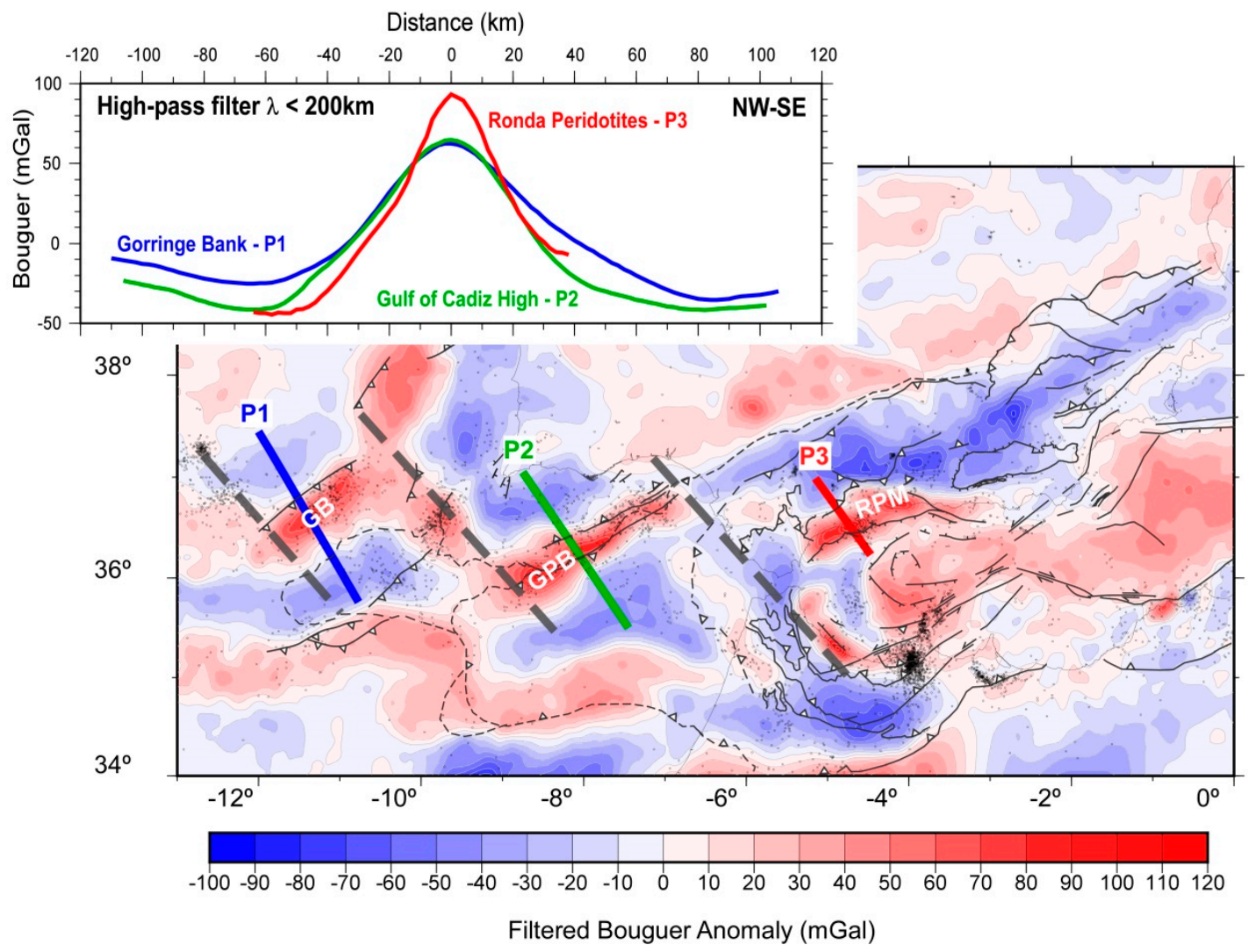

Figure 3. Filtered Bouguer gravity anomaly map of the Iberia-Africa plate boundary region after applying a high-pass filter of $200 \mathrm{~km}$ wavelength to the total Bouguer anomaly map shown in Figure 2. Profiles P-1 to P-3 indicate the locations of the modeled cross sections shown in Figure 4 with gravity values displayed in the inset. Tectonic background as in Figure 1. Thick discontinuous gray lines indicate the suggested transform zones separating the margin segments. GB: Gorringe Bank; GPB: Guadalquivir-Portimao Bank; RPM: Ronda Peridotite Massif. Dots denote epicenter locations with $\mathrm{M} \geq 3$ for period 1998-2016 taken from Instituto Geográfico Nacional, Earthquakes catalog https://www.ign.es/ign/layoutIn/sismoFormularioCatalogo.do.

The structure of the GB responsible for the residual Bouguer anomaly is known from seismic reflection and refraction, integrated modeling, and structural geology [22,23] and references therein]. Those authors agree that the GB is a transtensional basin that formed during the opening of the Central Atlantic exhuming serpentinized peridotites and oceanic crust that was subsequently inverted during the late Oligocene-early Miocene with a minimum shortening of $20 \mathrm{~km}$. The inferred degree of serpentinization varies from $70 \%$ to $80 \%$ at the top of the GB to less than $5 \%$ to $10 \%$ at $20 \mathrm{~km}$ depth. 

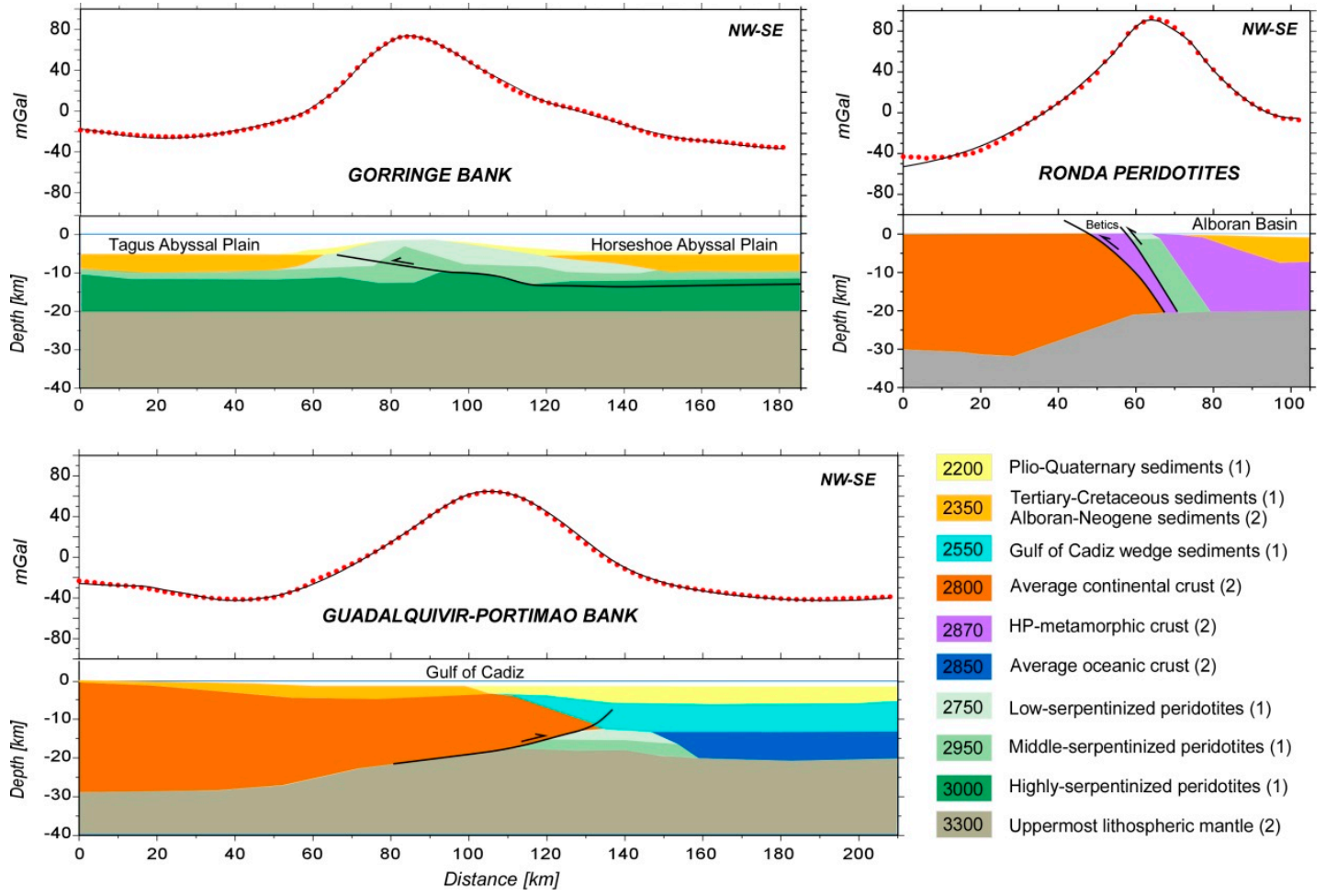

Figure 4. Gravity modelling of filtered Bouguer anomaly of simplified crustal cross sections across the Gorringe Bank, the Guadalquivir-Portimao Bank, and the Ronda Peridotite Massif (see locations in Figure 3). The legend indicates the adopted lithologies and density values $\left(\mathrm{kg} / \mathrm{m}^{3}\right)$ from the work of [23] (1) and this study (2). HP, high pressure.

The gravity high associated with the GPB and located in the Algarve margin has been modeled by the authors of [24], using multichannel seismic reflection and exploration well data as constraints. These authors propose that the gravity anomaly is mainly the result of a SE crustal thinning of $10-15 \mathrm{~km}$ combined with a basement high of 3-4 km as a response of the tectonic inversion of the Mesozoic hyper-extended margin. The most distal part of the Algarve margin could be floored by serpentinized mantle. In a further work based on reprocessing of IAM multichannel seismic data [25], it was concluded that the anomaly could partially reflect the influence of an intracrustal magmatic intrusion [26]. More recently, a large magmatic intrusion $\left(\sim 8000 \mathrm{~km}^{3}\right)$ along the necking domain of the margin, close to the ocean-continental transition, to reproduce the observed magnetic anomalies, has been proposed [27]. Tectonic inversion occurred during late Cretaceous-Paleocene, Oligocene-early Miocene, and late Pliocene-Recent periods, with an estimated shortening across the Algarve Basin of 5-10 km, less than $10 \%$ [28].

The Ronda Peridotite Massif (RPM) is exposed near the northwest coastline of the Alboran basin, forming the world's largest peridotite outcrop $(\sim 30 \mathrm{~km} \times \sim 10 \mathrm{~km})$. The region of the RPM has been the subject of extensive research to unravel its deep structure and the tectonic processes leading to mantle exhumation. The RPM consists of tectonically stacked peridotite sheets or a mantle extrusion wedge emplaced by the retreating of a subduction slab at around $20 \mathrm{Ma}[4,19,29-31]$. These mantle peridotite rocks could be either restricted to the upper-middle crust [32] or rooted into the lithospheric mantle [33,34]. The direction of emplacement and shortening undergone by these structures are uncertain and highly debated.

As mentioned, the three crustal-scale structures along the Iberia-Africa plate boundary (Gorringe Bank, Guadalquivir-Portimao Bank, and Ronda Peridotite Massif) have been studied independently by means of gravity models by different authors. To make comparable the results of gravity modelling along the selected profiles shown in Figure 3, we used similar lithologies and densities in the three 
sections according to the lateral continuity of known geological structures. Consequently, in the adopted models shown in Figure 4, we used a simplified crustal structure from the referred previous works. The filtered Bouguer gravity anomalies (Figure 3) reflect those relevant structures producing gravity anomalies with wavelengths of $<200 \mathrm{~km}$. This is the case of the crustal-scale thrusting related to the peridotite emplacement in the Gorringe Bank and thrust stacking in the Ronda massif, as well as of the crustal thinning associated with the south Iberian margin in both the Algarve margin and Alboran basin regions (Figure 2).

The gravity models were performed using Geosoft commercial software and based on the methods described in the works of [35,36] and the algorithms described in the work of [37]. Densities are considered constant within each layer. For the GB, we adopted the geometry and densities described in the work of [23] and, therefore, we have distinguished a Plio-Quaternary sedimentary layer overlying on top of Tertiary and Cretaceous sediments, which, in turn, are on top of exhumed mantle with different degrees of serpentinization (Figure 4). The geometry used for the Guadalquivir-Portimao Bank was derived by combining different proposed crustal models $[5,24,38,39]$, and we have not included the magmatic bodies described by the authors of $[26,27]$ as their main influence is on the magnetic anomalies, which are out of the scope of this study. The sedimentary sequences corresponding to the proximal domain of the margin were simplified to a single Cretaceous-Tertiary sedimentary layer with an average density of $2350 \mathrm{~kg} / \mathrm{m}^{3}$ incorporating Neogene-Quaternary, Paleogene, Cretaceous, and Jurassic sediments laying on top of the average continental crust. In the distal and oceanic domains of the margin, the upper crust contains a thick layer incorporating late Miocene and Quaternary sediments, which is overlying the Paleogene, Cretaceous, and Jurassic sequences forming the Gulf of Cadiz Wedge sediments (Figure 4). The deep crustal layers are formed by oceanic crust and serpentinized mantle. Finally, for the Ronda peridotites, we adopted the geometry proposed by the authors of [33], where we consider a similar average continental crust as in the GPB, and the HP metamorphic slices forming the Internal Betics and the Alboran basement, together with the serpentinized peridotites of Ronda. The basement of the Alboran Basin is covered by a thick sequence of Neogene and Plio-Quaternary sediments.

Gravity analysis is not unequivocal and thus cannot resolve by itself the characteristics of rocks, the exact volume of anomalous-density bodies, and the position and behavior of a tectonic contact. Despite these limitations, we can infer the major structural features across the segments of the Gorringe Bank, the Guadalquivir-Portimao Bank, and the Ronda/Beni-Bousera massifs, which are aligned in an en-echelon transpressive system along the Iberia-Africa plate boundary (Figure 3). The three segments all share a SW-NE orientation, a compressive tectonic inversion of hyper-extended margin segments, the presence of serpentinized upper mantle at different depths, and the age of thrusting (Figure 4). In the next section, we discuss their possible tectonic evolution in the framework of the IAPB considering some of the previously proposed models.

\section{Discussion}

Evidence for present segmentation of the IAPB is provided by recent seismological studies. A precise relocation of seismic events, from 1996 to 2013, shows a clear clustering along the major structures in both the GB and the GPB, indicating that these structures are still active [40]. Local earthquake tomography shows a high P-wave velocity body coinciding with surface exposures of the Ronda and Beni-Bousera peridotites and extending more than $200 \mathrm{~km}$ along the western Alboran coastline of Iberia and from the surface to a depth of $24 \mathrm{~km}$ [41]. This suggests that ultramafic/metamorphic slices are rooted into the mantle and extend at depth along most of the Betic-Rif orogen. Finally, full-waveform tomography in the Western Mediterranean shows that, in addition to the well-described Alboran slab, there is an E-W-trending positive velocity anomaly at $200-300 \mathrm{~km}$ depth beneath the Algerian margin, which may correspond to a remnant of the Algerian-Tethys retreated slab [42]. 
From these considerations and the previous analysis of gravity anomalies, we conclude the following: (1) the three segments of the IAPB are NE-SW trending and extend along 150-180 km in the Gorringe Bank, 170-200 km in the Guadalquivir-Portimao segment, and 300-350 km in the Ronda/Beni-Bousera segment; (2) the presence of peridotites in the outcrop or at depth implies the development of hyperextended margins with mantle exhumation during the Jurassic; and (3) the final emplacement of the peridotites and metamorphic units as well as the structural geometry of segments is associated with the Alpine tectonics.

Thus, any tectonic evolution model of the IAPB must account for the development of margin segmentation, the spatial distribution of high-pressure (HP/LT) metamorphism, and the closure of the Tethyan domains. Whereas there is a general agreement in that the present structure of the Gorringe Bank and the Guadalquivir-Portimao Bank resulted from tectonic inversion of the inherited Jurassic hyper-extended margins, the relationship of the Ronda Peridotite Massif and Internal Betics with the Jurassic segmentation is more debatable. Among the diversity of conceptual models on the tectonic evolution of the Betic-Rif orogenic system, there are two end-member propositions supporting that the structure of the RPM and associated metamorphic units resulted either from the Alpine tectonics solely or that it shows a substantial Jurassic heritage component (see, for example, the works of $[4,7,18,19,43]$ for thorough reviews).

The first conceptual model considers that the RPM and the associated metamorphic units resulted from NW-directed subduction of the Ligurian-Tethys, which was confined to the Balearic-Sardinia/Corsica segment [7,18,44]. At $30 \mathrm{Ma}$ (early Oligocene), subduction beneath the Balearic segment amounted to $\sim 150 \mathrm{~km}$ increasing beneath the Sardinia/Corsica segment. HP/LT metamorphic units were already buried at a depth of $40-60 \mathrm{~km}$ before the inception of rollback. According to the authors of [7], slab rollback initiated after $30 \mathrm{Ma}$ and the North Balearic Transform Fault (NBTF) separated the Calabrian slab from the Algerian/Alboran slab. At 16 Ma (Langhian/Burdigalian), the rollback of the Algerian slab ended and the Kabylies collided with north-Africa. From this time on, the Alboran domain moved westwards until colliding with south-Iberia/north-Africa, forming the Betic-Rif orogen.

This model is constrained by plate kinematic reconstructions [17] and is consistent with the total area of the high velocity slab beneath the Betic-Rif orogen imaged from tomography models [44,45], and with dynamic modelling [46]. The model, however, requires key tectonic structures to explain the $\sim 180$ clockwise trench rotation around the eastern termination of the Betics; the westward displacement of the trench of more than $600 \mathrm{~km}$; and an average retreat velocity of $37.5 \mathrm{~mm} / \mathrm{yr}$ over the last $16 \mathrm{Myr}$, with maximum values of $80 \mathrm{~mm} / \mathrm{yr}$ [7]. The key structures advocated by these authors are three subduction-transform edge propagator (STEP) faults: the NBTF, which acted as a STEP fault during the separation of the Corsica/Sardinia and the Algerian/Alboran slabs after $30 \mathrm{Ma}$ (early Oligocene); and the Emile-Baudot transform fault, limiting the southeastern edge of the Balearic Promontory and the North Africa transform fault, both acting as STEP faults allowing for the westward displacement of the Alboran domain after $16 \mathrm{Ma}$.

In the extensive review on the Betic-Rif Arc and its orogenic hinterland, it is proposed that the formation of the arc was driven by the gravitational potential energy contrast between the Alboran domain and the Iberian and African margins [19]. Such energy contrast would be caused by a $50-55 \mathrm{~km}$ thick crust in the Alboran domain at $24 \mathrm{Ma}$ (late Oligocene), and generating an elevation of 4-5 km [47]. This crustal thickening, produced by the long-standing Iberia-Africa convergence, would be located $\sim 250 \mathrm{~km}$ to the SE of the present position of the arc and, therefore, the lateral migration of the Alboran domain would be much smaller than that proposed by the authors of [7]. Leaving aside the differences between both models concerning the tectonic mechanisms responsible for the HP/LT metamorphism and the emplacement of the internal units, none of them include the Atlantic segments of the Iberia-Africa plate boundary.

A major drawback of these models is that they restrict the tectonic evolution of the region from Middle Eocene to recent, ignoring the previous stages despite the plentiful evidence of compressive 
deformation. Plate reconstruction models suggest that Iberia-Africa convergence between chrons 34 and $18(83.6-39 \mathrm{Ma})$ is about $50-80 \mathrm{~km}[16,17]$. Four tectonic episodes associated with the deposition of olistostromes in the Central Betics from Late Jurassic to Early Miocene, with particular relevance to the $\mathrm{N}$-directed shortening in the Late Cretaceous-Paleocene period, have been described [48]. Compressive tectonic pulses affecting the External Betics lasting from Coniacian-Santonian to Paleocene-early Eocene are described by several authors [49-51]. Consequently, mixed carbonate-siliciclastic platforms, SW-NE oriented troughs with debris flow, and inversion of extensional faults were developed. Despite this evidence, models proposing a large westward displacement of the Alboran domain [7,18,44] disregard the effects of shortening in the south-Iberian margin, whereas other models, which consider a more autochthonous position of the Betic-Rif chain, require that at $50 \mathrm{Ma}$, the Internal Betics are buried at a depth of 40-60 $\mathrm{km}[19,52]$.

Here, we propose an alternative tectonic model of this diffuse plate boundary region that incorporates both the Atlantic and the Mediterranean domains, and the evolution from Early Jurassic to recent, as shown in Figure 5. The grounds of the model are based on the plate reconstruction model from the work of [16] and the evolution of the Betic-Rif orogen from the work of [4] incorporating recent works focusing on the different plate boundary segments [22-24,43].

The margin segmentation initiated with the eastward displacement of Africa relative to Iberia during the Jurassic, creating the Ligurian-Alpine-Tethys Ocean bounded by highly extended margins with exhumation of mantle rocks and oceanic type volcanism (Figure $5 a, b$ ).

This marked segmentation allowed opposed subduction/retreating polarities to develop in adjacent segments during the N-S Africa-Eurasia convergence, with the Algerian-Tethys segment dipping northwest and the Alboran-Tethys segment corresponding to the present Betic-Rif or Ronda/Beni-Bousera segment dipping southeast. Further west, convergence was accommodated by SE-directed thrusting in the Guadalquivir-Portimao Bank segment and by NW-directed thrusting in the Gorringe Bank segment (Figure $5 \mathrm{c}$,d).

It is worth noting that the estimated shortening of 5-10 km in the GPB [28] contrasts with the calculated convergence since chron 34 to recent of $100 \mathrm{~km} \mathrm{[16]} \mathrm{to} 150 \mathrm{~km}$ [17], thus suggesting that most of the convergence is not accommodated by the GPB, but by structures located in the southern Gulf of Cadiz or further north of the GPB. The progressive southeastward retreat of the Algerian-Tethys segment generated new oceanic crust during the early Miocene, whereas the northwestward retreat of the Alboran-Tethys domain produced a marked crustal thinning. The higher resistance of the slab to retreat produced by the continental block adjacent to the western end of the segment caused the progressive trench curvature [53]. Roll-back of the Alboran-Tethys and Algerian-Tethys subducted domains also resulted in the emplacement of HP metamorphic slices in the Betic-Rif and the Kabylies, respectively. The effects related to subduction and slab retreat almost ceased during the late Miocene, although Iberia-Africa convergence is still active, further tightening the Betic-Rif arc into its present-day geometry [43,54] (Figure 5e,f).

As a consequence of the evolution of the IAPB described above, the Gloria Fault-located west of the Gorringe Bank and out of the study region-separates the Jurassic Central Atlantic and Early Cretaceous North Atlantic oceans, the former being floored by typical oceanic crust and the latter by exhumed and serpentinized upper mantle close to the GB. Between the GB and the Gibraltar Strait, the plate boundary corresponds to Jurassic Tethys segments with oceanized crust and/or exhumed serpentinized mantle bounded by hyper-extended continental margins; see also the work of [5]. Further east, the westernmost Mediterranean is floored by HP metamorphic basement (Alboran segment), which transitions to a highly intruded and oceanic-type Neogene crust (Algerian segment). The feasibility of tectonic processes dominated by opposite subduction polarity in adjacent plate segments has been demonstrated by analog modelling [55]. The diffuse character of the IAPB is related to (i) the complex tectonic pattern resulting from the convergence between the Iberia and Africa margins with its inherited en-echelon geometry, (ii) the arcuate slab roll-back of the Alboran segment with the formation of an accretionary wedge in the Gulf of Cadiz and the back-arc Alboran 
basin, and (iii) the tightening of the Betic-Rif orogen owing to protracted Iberia-Africa convergence. The proposed segments are the remnants of the Jurassic-Cretaceous plate boundary and may not coincide with the present boundary because the IAPB is still undergoing reorganization $[14,56]$.

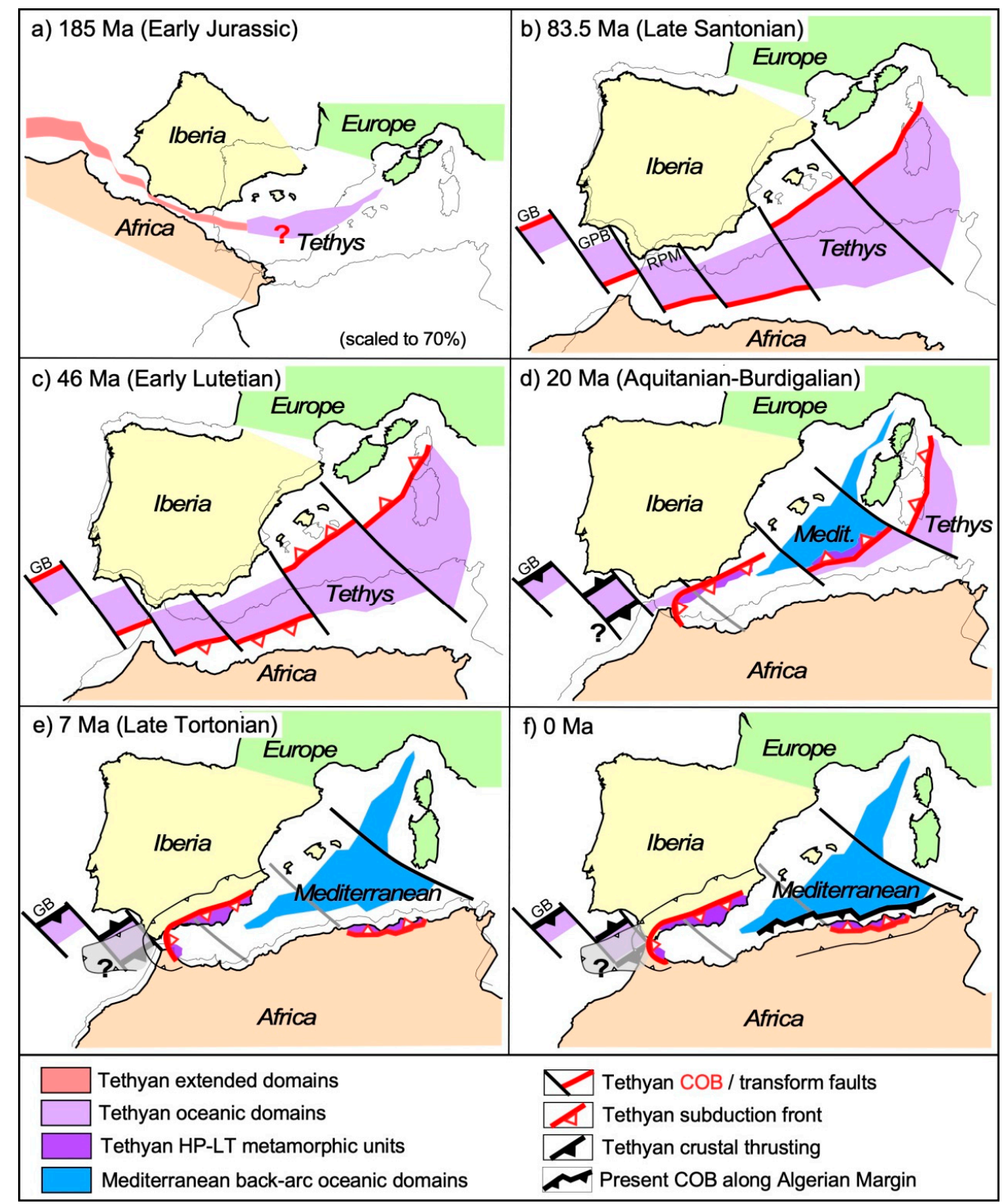

Figure 5. Sketch summarizing the tectonic evolution of the Iberia-Africa plate boundary since the Early Jurassic: (a) oceanic spreading in the Central Atlantic with eastward displacement of Africa relative to Iberia and opening of the Ligurian-Tethys; (b) initiation of N-S Iberia-Africa convergence and end of extension in the Ligurian-Tethys segments; (c) development of thrusting and subduction with opposite polarity in the Ligurian-Tethys segments; (d) roll-back of the subducted Ligurian-Tethys segments and generation of the present Mediterranean; (e) end of roll-back of the Ligurian-Tethys slabs and stacking of the high-pressure/low-temperature (HP/LT) units in the Betic-Rif Arc and the Kabylies; and (f) possible initiation of S-SE directed subduction of the Mediterranean domain beneath north-Africa. COB: continental-oceanic boundary; GB: Gorringe Bank; GPB: Guadalquivir-Portimao Bank; RPM: Ronda Peridotite Massif. Plate reconstruction from 83.5 Ma to present taken from the work of [16]. 


\section{Conclusions}

From this study we conclude that (1) the filtered Bouguer gravity map shows three major anomalies of similar wavelength and amplitude coinciding, from west to east, with the tectonic structures of the Gorringe Bank, the Guadalquivir-Portimao Bank, and the Ronda/Beni-Bousera peridotites; (2) density/gravity modeling shows that these anomalies are compatible with the tectonic inversion of highly extended margins involving exposed or 'underplated' peridotites in the Atlantic domain, and stacked slices of peridotite in the Mediterranean domain; and (3) these tectonic structures delineate three segments of the transtensional Iberia-Africa plate boundary that are inherited from the Jurassic Ligurian-Tethys segmentation and have been mostly preserved since then.

These findings allowed us to propose a model for the tectonic evolution of the segmented Iberia-Africa Plate Boundary, whose main novelty is the integration of the plate boundary segments pertaining to both the Atlantic and the Mediterranean domains consistently with plate kinematic reconstructions. The reactivation of major structures related to this inherited segmentation constrains the Alpine compressive evolution of the IAPB and allows for lateral variations in dip polarity during the subduction of the Ligurian-Tethys segments, suggesting that there is no continuity between the subducting lithospheric slab underneath the Betic-Rif orogen and the Tethys oceanic crust in the Atlantic domain. In this sense, the present work completes our own interpretations about the independent evolution of these segments $[3,4,22,43]$ and makes a relevant difference with respect to models proposed by other authors $[5-7,18,19,44,46]$.

Author Contributions: Conceptualization, M.F., M.T. and J.V.; Formal analysis, M.T. and M.F.; Funding acquisition, J.V.; Visualization, M.T., J.V., E.C. and C.M.; Writing, M.F.

Funding: This research was funded by the Consejo Superior de Investigaciones Científicas, grant number ALPIMED-CSIC-201530E082 and by the Agencia Estatal de Investigación, grant number MITE-CGL2014-59516-P.

Acknowledgments: We are indebted to two anonymous reviewers who provided very interesting and helpful comments and suggestions that largely improved the original version of the manuscript.

Conflicts of Interest: The authors declare no conflict of interest.

\section{References}

1. Stampfli, G.; Borel, G.D. A plate tectonic model for the Paleozoic and Mesozoic constrained by dynamic plate boundaries and restored synthetic oceanic isochrones. Earth Planet. Sci. Lett. 2002, 196, 17-33. [CrossRef]

2. Schettino, A.; Turco, E. Tectonic history of the western Tethys since the Late Triassic. Geol. Soc. Am. Bull. 2011, 123, 89-105. [CrossRef]

3. Jiménez-Munt, I.; Fernàndez, M.; Torne, M.; Bird, P. The transition from linear to diffuse plate boundary in the Azore-Gibraltar region: Results from a thin-sheet model. Earth Planet. Sci. Lett. 2001, 192, 175-189. [CrossRef]

4. Vergés, J.; Fernàndez, M. Tethys-Atlantic interaction along the Iberia-Africa plate boundary: The Betic-Rif orogenic system. Tectonophysics 2012, 579, 144-172. [CrossRef]

5. Martínez-Loriente, S.; Sallarès, S.; Gràcia, E.; Bartolome, R.; Dañobeitia, J.J.; Zitellini, N. Seismic and gravity constraints on the nature of the basement in the Africa-Eurasia plate boundary: New insights for the geodynamic evolution of the SW Iberian margin. J. Geophys. Res. Solid Earth. 2014, 119, 127-149. [CrossRef]

6. Faccenna, C.; Becker, T.W.; Auer, L.; Billi, A.; Boschi, L.; Brun, J.P.; Capitanio, F.A.; Funiciello, F.; Horvàth, F.; Jolivet, L.; et al. Mantle dynamics in the Mediterranean. Rev. Geophys. 2014, 52, 283-332. [CrossRef]

7. Van Hinsbergen, D.; Vissers, R.; Spakman, W. Origin and consequences of western Mediterranean subduction, rollback, and slab segmentation. Tectonics 2014, 33, 393-419. [CrossRef]

8. Fullea, J.; Fernàndez, M.; Afonso, J.C.; Verges, J.; Zeyen, H. The structure and evolution of the lithosphere-asthenosphere boundary beneath the Atlantic-Mediterranean Transition Region. Lithos 2010, 120, 74-95. [CrossRef]

9. Nirrengarten, M.; Manatschal, G.; Tugend, J.; Kusznir, N.; Sauter, D. Kinematic Evolution of the Southern North Atlantic: Implications for the Formation of Hyperextended Rift Systems. Tectonics 2018, 37, 89-118. [CrossRef] 
10. Vergés, J.; Fernàndez, M. Ranges and basins in the Iberian Peninsula: Their contribution to the present topography. Geol. Soc. Mem. 2006, 32, 223-234. [CrossRef]

11. Vergés, J.; Kullberg, J.C.; Casas-Sainz, A.; de Vicente, G.; Duarte, L.V.; Fernàndez, M.; Gómez, J.J.; Gómez-Pugnaire, M.T.; Jabaloy Sánchez, A.; López-Gómez, J.; et al. An Introduction to the Alpine Cycle in Iberia; Quesada, C., Oliveira, J.T., Eds.; The Geology of Iberia: A Geodynamic Approach; Springer: Berlin, Germany, 2019; pp. 1-14.

12. Jiménez-Munt, I.; Bird, P.; Fernàndez, M. Thin-shell modeling of neotectonics in the Azores-Gibraltar region. Geophys. Res. Lett. 2001, 28, 1083-1086. [CrossRef]

13. Iribarren, L.; Vergés, J.; Camurri, F.; Fullea, J.; Fernàndez, M. The structure of the Atlantic-Mediterranean transition zone from the Alboran Sea to the Horseshoe Abyssal Plain (Iberia-Africa plate boundary). Mar. Geol. 2007, 243, 97-119. [CrossRef]

14. Zitellini, N.; Gràcia, E.; Matias, L.; Terrinha, P.; Abreu, M.A.; DeAlteriis, G.; Henriet, J.P.; Dañobeitia, J.J.; Masson, D.G.; Mulder, T.; et al. The quest for the Africa-Eurasia plate boundary west of the Strait of Gibraltar. Earth Planet. Sci. Lett. 2009, 280, 13-50. [CrossRef]

15. Palano, M.; González, P.J.; Fernéndez, J. The Diffuse Plate boundary of Nubia and Iberia in the Western Mediterranean: Crustal deformation evidence for viscous coupling and fragmented lithosphere Earth Planet. Sci. Lett. 2015, 430, 439-447. [CrossRef]

16. Macchiavelli, C.; Vergés, J.; Schettino, A.; Fernàndez, M.; Turco, E.; Casciello, E.; Torne, M.; Pierantoni, P.P.; Tunini, L. A new southern North Atlantic isochron map: Insights into the drift of the Iberian plate since the Late Cretaceous. J. Geophys. Res. Solid Earth 2017, 122, 9603-9626. [CrossRef]

17. Vissers, R.L.M.; Meijer, P.T. Iberian plate kinematics and Alpine collision in the Pyrenees. Earth-Sci. Rev. 2012, 114, 61-83. [CrossRef]

18. Rosenbaum, G.; Lister, G.S. Formation of arcuate orogenic belts in the western Mediterranean region. In Orogenic Curvature: Integrating Paleomagnetic and Structural Analyses; Sussman, A.J., Weil, A.B., Eds.; Geological Society of America Special Paper: Boulder, CO, USA, 2004; Volume 383, pp. 41-56.

19. Platt, J.P.; Behr, W.M.; Johanesen, K.; Williams, J.R. The Betic-Rif Arc and Its Orogenic Hinterland: A Review. Annu. Rev. Earth Planet. Sci. 2013, 41, 313-357. [CrossRef]

20. David, T.S.; Dietmar, M.; Walter, H.F.S.; Emmanuel, G.; Richard, F. New global marine gravity model from CryoSat-2 and Jason-1 reveals buried tectonic structure. Science 2014, 346, 65-67. [CrossRef]

21. Ayala, C.; Bohoyo, F.; Maestro, A.; Reguera, M.I.; Tprne, M.; Rubio, F.; Fernàndez, M.; García-Lobón, J.L. Updated Bouguer anomalies of the Iberian Peninsula: A new perspective to interpret the regional geology. J. Maps 2016, 12, 1089-1092. [CrossRef]

22. Jiménez-Munt, I.; Fernàndez, M.; Vergés, J.; Afonso, J.C.; Garcia-Castellanos, D.; Fullea, J. Lithospheric structure of the Gorringe Bank: Insights into its origin and tectonic evolution. Tectonics 2010, 29, TC5019. [CrossRef]

23. Sallarès, V.; Martínez-Loriente, S.; Prada, M.; Gràcia, E.; Ranero, C.; Gutscher, M.A.; Bartolome, R.; Gailler, A.; Dañobeitia, J.J.; Zitellini, N. Seismic evidence of exhumed mantle rock basement at the Gorringe Bank and the adjacent Horseshoe and Tagus abyssal plains (SW Iberia). Earth Planet. Sci. Lett. 2013, 365, 120-131. [CrossRef]

24. Ramos, A.; Fernández, O.; Torné, M.; Sánchez de La Muela, A.; Muñoz, J.A.; Terrinha, P.; Manatschal, G.; Salas, M.C. Crustal structure of the SW Iberian passive margin: The westernmost remnant of the Ligurian Tethys? Tectonophysics 2017, 705, 42-62. [CrossRef]

25. Banda, E.; Torne, M. Iberian Atlantic Margins Group investigates deep structure of ocean margins. Eos. Trans. $1995,76,25-29$.

26. Buffett, G.; Torne, M.; Carbonell, R.; Melchiore, M.; Vergés, J.; Fernández, M. The nature of crustal reflectivity at the southwest Iberian margin. Tectonophysics 2017, 721, 239-253. [CrossRef]

27. Neres, M.; Terrinha, P.; Custódio, S.; Silva, S.M.; Luis, J.; Miranda, J.M. Geophysical evidence for a magmatic intrusion in the ocean-continent transition of the SW Iberia margin. Tectonophysics 2018, 744, 118-133. [CrossRef]

28. Ramos, A.; Fernández, O.; Terrinha, P.; Muñoz, J.A. Neogene to recent contraction and basin inversion along the Nubia-Iberia boundary in SW Iberia. Tectonics 2017, 36, 257-286. [CrossRef] 
29. Garrido, C.J.; Gueydan, F.; Booth-Rea, G.; Precigout, J.; Hidas, K.; Padron-Navarta, J.A.; Marchesi, C. Garnet lherzolite and garnet-spinel mylonite in the Ronda peridotite: Vestiges of Oligocene backarc mantle lithospheric extension in the western Mediterranean. Geology 2011, 39, 927-930. [CrossRef]

30. Précigout, J.; Gueydan, F.; Garrido, C.J.; Cogné, N.; Booth-Rea, G. Deformation and exhumation of the Ronda peridotite (Spain). Tectonics 2013, 32, 1011-1025. [CrossRef]

31. Frasca, G.; Gueydan, F.; Brun, J.-P.; Monié, P. Deformation mechanisms in a continental rift up to mantle exhumation. Field evidence from the western Betics, Spain. Mar. Pet. Geol. 2016, 76, 310-328. [CrossRef]

32. Torne, M.; Banda, E.; García-Dueñas, V.; Balanyá, J.C. Mantle-lithosphere bodies in the Alboran crustal domain (Ronda peridotites, Betic-Rif orogenic belt). Earth Planet. Sci. Lett. 1992, 110, 163-171. [CrossRef]

33. Mazzoli, S.; Martín-Algarra, A. Deformation partitioning during transpressional emplacement of a 'mantle extrusion wedge': The Ronda peridotites, western Betic Cordillera, Spain. J. Geol. Soc. 2011, 168, 373-382. [CrossRef]

34. Gueydan, F.; Mazzotti, S.; Tiberi, C.; Cavin, R.; Villaseñor, A. Western Mediterranean sub-continental mantle emplacement by continental margin obduction. Tectonics 2019, 38, 2142-2157. [CrossRef]

35. Talwani, M.; Heirtzler, J.R. Computation of magnetic anomalies caused by two dimensional bodies of arbitrary shape. In Computers in the Mineral Industries, Part 1, Geol. Sci. 9; Parks, G.A., Ed.; Stanford University Publisher: Stanford, CA, USA, 1964; pp. 464-480.

36. Talwani, M.; Worzel, J.L.; Landisman, M. Rapid gravity computations for two dimensional bodies with application to the Mendocino submarine fracture zone. J. Geophys. Res. 1959, 64, 49-59. [CrossRef]

37. Won, I.J.; Bevis, M. Computing the gravitational and magnetic anomalies due to a polygon: Algorithms and Fortran subroutines. Geophysics 1987, 52, 232-238. [CrossRef]

38. Gràcia, E.; Dañobeitia, J.; Vergés, J.; Bartolomé, R. Crustal architecture and tectonic evolution of the Gulf of Cadiz (SW Iberian margin) at the convergence of the Eurasian and African plates. Tectonics 2003, 22, 1-18. [CrossRef]

39. Gutscher, M.-A.; Dominguez, S.; Westbrook, G.K.; Le Roy, P.; Rosas, F.; Duarte, J.C.; Terrinha, P.; Miranda, J.M.; Graindorge, D.; Gailler, A.; et al. The Gibraltar subduction: A decade of new geophysical data. Tectonophysics 2012, 574-575, 72-91. [CrossRef]

40. Custódio, S.; Dias, N.A.; Carrilho, F.; Góngora, E.; Rio, I.; Marreiros, C.; Morais, I.; Alves, P.; Matias, L. Earthquakes in western Iberia: Improving the understanding of lithospheric deformation in a slowly deforming region. Geophys. J. Int. 2015, 203, 127-145. [CrossRef]

41. El Moudnib, L.; Villaseñor, A.; Harnafi, M.; Gallart, J.; Pazos, A.; Serrano, I.; Córdoba, D.; Pulgar, J.A.; Ibarra, P.; Himmi, M.M.; et al. Crustal structure of the Betic-Rif system, western Mediterranean, from local earthquake tomography. Tectonophysics 2015, 643, 94-105. [CrossRef]

42. Fichtner, A.; Villaseñor, A. Crust and upper mantle of the western Mediterranean - Constraints from full-waveform inversion. Earth Planet. Sci. Lett. 2015, 428, 52-62. [CrossRef]

43. Casciello, E.; Fernàndez, M.; Vergés, J.; Cessarano, M.; Torne, M. The Alboran Domain in the Western Mediterranean evolution: The birth of a concept. Bull. Soc. Géol. 2015, 186, 23-34. [CrossRef]

44. Spakman, W.; Wortel, R. The TRANSMED Atlas: The Mediterranean Region from Crust to Mantle. In $A$ Tomographic View on Western Mediterranean Geodynamics; Cavazza, W., Roure, F., Spakman, W., Stampfli, G.M., Ziegler, P., Eds.; Springer: Berlin/Heidelberg, Germany, 2004; pp. 31-52.

45. Bezada, M.J.; Humphreys, E.D.; Toomey, D.R.; Harnafi, M.; Dávila, J.M.; Gallart, J. Evidence for slab rollback in westernmost Mediterranean from improved upper mantle imaging. Earth Planet. Sci. Lett. 2013, 368, 51-60. [CrossRef]

46. Chertova, M.V.; Spakman, W.; Geenen, T.; van den Berg, A.P.; van Hinsbergen, D.J.J. Underpinning tectonic reconstructions of the western Mediterranean region with dynamic slab evolution from 3-D numerical modeling. J. Geophys. Res.: Solid Earth 2014, 119, 5876-5902. [CrossRef]

47. Platt, J.P. From orogenic hinterlands to Mediterranean-style back-arc basins: A comparative analysis. J. Geol. Soc. 2007, 164, 297-311. [CrossRef]

48. Comas, M.C. Sobre la geología de los Montes Orientales: Sedimentación y evolución paleogeográfica desde el Jurásico al Mioceno inferior (Zona Subbética, Andalucía). Ph.D. Thesis, University de Bilbao, Bizkaia, Spain, 1978. 
49. Martín-Chivelet, J.; Chacón, B. Event stratigraphy of the upper Cretaceous to lower Eocene hemipelagic sequences of the Prebetic Zone (SE Spain): Record of the onset of tectonic convergence in a passive continental margin. Sediment. Geol. 2007, 197, 141-163. [CrossRef]

50. Reicherter, K.R.; Pletsch, T.K. Evidence for a synchronous circum-Iberian subsidence event and its relation to the African-Iberian plate convergence in the Late Cretaceous. Terra Nova 2000, 12, 141-147. [CrossRef]

51. Vilas, L.; Martín-Chivelet, J.; Arias, C. Integration of subsidence and sequence stratigraphic analyses in the Cretaceous carbonate platforms of the Prebetic (Jumilla-Yecla Region), Spain. Palaeogeogr. Palaeoclimatol. Palaeoecol. 2003, 200, 107-129. [CrossRef]

52. Platt, J.P.; Kelley, S.P.; Carter, A.; Orozco, M. Timing of tectonic events in the Alpujárride Complex, Betic Cordillera, southern Spain. J. Geol. Soc. 2005, 162, 451-462. [CrossRef]

53. Peral, M.; Zlotnik, S.; Fernàndez, M.; Vergés, J.; Kumar, A.; Ruh, J. A numerical model of the Western Mediterranean. Geophys. Res. Abstr. 2019, 21, EGU2019-9312.

54. Crespo-Blanc, A.; Comas, M.; Balanyá, J.C. Clues for a Tortonian reconstruction of the Gibraltar Arc: Structural pattern, deformation diachronism and block rotations. Tectonophysics 2016, 683, 308-324. [CrossRef]

55. Peral, M.; Király, A.; Zlotnik, S.; Funiciello, F.; Fernàndez, M.; Faccenna, C.; Vergés, J. Opposite subduction polarity in adjacent plate segments. Tectonics 2018, 37, 3285-3302. [CrossRef]

56. Déverchère, J.; Yelles, K.; Domzig, A.; Mercier de Lépinay, B.; Boullin, J.P.; Gaullier, V.; Bracène, R.; Calais, E.; Savoye, B.; Kherroubi, A.; et al. Active thrust faulting offshore Boumerdes, Algeria, and its relations to the 2003 Mw 6.9 earthquake. Geophys. Res. Lett. 2005, 32, 1-5. [CrossRef]

(C) 2019 by the authors. Licensee MDPI, Basel, Switzerland. This article is an open access article distributed under the terms and conditions of the Creative Commons Attribution (CC BY) license (http://creativecommons.org/licenses/by/4.0/). 